\title{
Pengembangan Board Game "Zathura Mathematics" Pada Materi Bilangan Berpangkat dan Bentuk Akar
}

\section{Dewi Wahyuningsih ${ }^{1}$ and Danang Setyadi}

\author{
1,2Fakultas Keguruan dan Ilmu Pendidikan Universitas Kristen Satya Wacana
}

Corresponding Author: 202016034@student.uksw.edu', danang.setyadi@staff.uksw.edu²

DOI: http://dx.doi.org/10.15294/kreano.v1 1i1.22493

Received: December 14 2019; Accepted: March 23 2020; Published: June 12020

\begin{abstract}
Abstrak
Motivasi merupakan aspek kunci pada pencapaian prestasi, belajar akan lebih ulet, mempelajari dan menguasai materi demi tujuan yang ingin dicapai. Penelitian ini bertujuan untuk mengembangkan Board Game Zathura Mathematics pada materi berpangkan dan bentuk akar. Penelitian ini termasuk dalam pengembangan atau Research and Development (R\&D) melalui 5 tahapan : Analysis (menganalisis), Design (mendesain), Development (mengembangkan), Implementation (melaksanakan), dan Evaluation (mengevaluasi). Media valid dari segi materi dan media pembelajaran dengan persentase $88 \%$ dan $87 \%$ dari kedua kategori tersebut masuk dalam kategori sangat baik untuk materi maupun media pembelajaran. Nilai praktis pada media ini sebesar $100 \%$ termasuk dalam kategori sangat baik. Board Game Zathura Mathematics valid dan praktis sebagai media pembelajaran materi Bilangan Berpangkat dan Bentuk Akar pada peserta didik kelas IX.
\end{abstract}

Kata Kunci: media pembelajaran; papan permainan; bilangan berpangkat; bentuk akar

\begin{abstract}
Motivation is a key aspect of achievement, learning will be more tenacious, learn and master the material for the objectives to be achieved. This study aims to develop the Zathura Mathematics Board Game on trunk material and root shapes. This research is included in the development or Research and Development $(R \& D)$ through 5 stages: Analysis (analyzing), Design (designing), Development (developing), Implementation (implementing), and Evaluation (evaluating). Media is valid in terms of material and learning media with a percentage of $88 \%$ and $87 \%$ of the two categories included in the excellent category for the material and learning media. The practical value of this media is $100 \%$ included in the excellent category. Zathura Mathematics Board Game is valid and practical as learning media for Rank Numbers and Root Shapes in grade IX students.
\end{abstract}

Keywords: learning media; board game; rank numbers and root shapes

\section{PENDAHULUAN}

Motivasi dalam belajar merupakan aspek kunci yang sangat penting pengaruhnya pada pencapaian prestasi belajar peserta didik (Hendriana, 2017), (Emda, 2017). Peserta didik yang termotivasi akan lebih ulet dalam belajar, mempelajari dan menguasai materi demi tujuan yang ingin dicapai (Suprihatin, 2015; Setyadi dan Qohar, 2017). Terdapat beberapa pendorong motivasi belajar salah satunya dengan mewujudkan suasana belajar yang menarik, sehingga pesersa didik dapat aktif mengembangkan potensinya (Ernata, 
2017).

Latif (2013) berpendapat bahwa penerapan media dalam proses pembelajaran merupakan salah satu cara untuk menciptakan suasana belajar yang menarik. Media pembelajaran yang menarik dan sesuai dengan kecakapan berpikir dan tingkat pemahaman peserta didik mengakibatkan peserta didik dapat terlibat aktif pada proses pembelajaran (Gianto, 2018). Selanjutnya Setyadi dan Qohar (2017) menyatakan bahwa pembelajaran yang menarik dapat membangkitkan minat peserta didik dalam belajar matematika yang pada akhirnya berhasil dalam memahami materi.

Terdapat beberapa jenis media pembelajaran salah satunya adalah media yang berbentuk permainan (Lutfianingsih, 2018). Beberapa media permainan telah dikembangkan diantaranya modul, kartu domino, labirin, uno stacko. Selain itu terdapat juga penelitian mengenai Board Game yaitu oleh Ahmad (2017). Board game KODAMA (kotak dadu matematika) media dikembangkan pada materi persamaan garis lurus. Kodama sendiri merupakan perpaduan permainan antara monopoli dan ular tangga.

Board Game merupakan komponen dari permainan pada permukaan yang sesuai dengan seperangkat aturan dan dapat ditempatkan maupun dipindahkan (Erlitasari dan Dewi, 2016). Penggunaan Board Game dapat membantu memudahkan peserta didik dalam memahami maupun mengingat kembali mengenai materi yang telah dipelajari melalui suasana nyaman (Triastuti, 2016). Hal ini juga didukung oleh Andini (2018) yang menyatakan bahwa dengan media yang menarik dan juga penerapan warna dan gambar yang sesuai dengan karakteristik peserta didik akan membangkitkan minat dalam belajar.

Terdapat beberapa peneliti telah menggembangkan media Board Game dan membuktikan dampak positif dari penggunaan media tersebut, diantaranya penelitian yang dilakukan oleh Anggreiny dan Bambang (2018), Putri (2018) dan Rosa (2018). Kesimpulan dari ketiga penelitian tersebut adalah media Board Game valid, praktis dan efektif sebagai media pembelajaran terutama dalam matematika. Media Board Game dapat membantu siswa mendapatkan pengalaman secara langsung dalam proses pembelajaran, sehingga dapat membantu kesulitan dalam belajar juga meningkatkan hasil belajar siswa.

Berdasarkan hal tersebut, peneliti akan mengembangkan Board Game yang mampu membantu peserta didik dalam pembelajaran. Board Game juga dapat digunakan sebagai alat belajar yang dikembangkan berdasarkan aspek validitas, kepraktisan, dan efektivitas terutama untuk belajar matematika pada materi bilangan berpangkat dan bentuk akar, serta sebagai sarana pelatihan bagi peserta didik dan dapat digunakan oleh pendidik guna meningkatkan Inovasi pembelajaran.

Peneliti tertarik untuk mengembangkan media Board Game pada materi bilangan berpangkat dan bentuk akar. Karakteristik material bilangan berpangkat dan bentuk akar membutuhkan media yang nyata, sebagai media penyampaian materi dan latihan soal yang lebih menyenangkan. Peserta didik dapat secara langsung berinteraksi dengan teman-teman sekeliling mereka melalui permainan ini. Nama Board Game yang akan dikembangkan oleh peneliti adalah "Zathura Mathematics".

\section{Model Pengembangan Addie}

Berikut pengembangan model ADDIE yang terdiri dari 5 tahapan: Analysis (menganalisis), Design (mendesain), Development (mengembangkan), Implementation (melaksanakan), dan Evaluation (mengevaluasi) (Sugiyono, 2009).

\section{Analysis (Analisis)}

Terdapat 2 tahapan analisis yaitu analisis karakter peserta didik dan analisis kebutuhan. Tahap pertama analisis karakter peserta didik dilaksanakan guna memahami karakteristik peserta didik tingkat SMP. Pada tahap kedua, yaitu analisis kebutuhan dilaksanakan guna mengetahui keadaan atau ketersediaan media sebagai sumber informasi pokok dalam pembelajaran.

\section{Design (Desain)}

Tahapan mendesain meliputi tahap mencipta dan menysun media. Pada tahap 
ini, peneliti juga menyusun instrumen untuk penilaian media. Instrumen dibuat dengan memperhatikan beberapa aspek diantaranya aspek media, materi, kepraktisan media dan angket respon peserta didik.

\section{Development (mengembangkan)}

Pada tahap ini termasuk tahapan membuat atau merealisasikan media sesuai dengan desain yang telah dibuat pada tahap sebelumnya. Kegiatan ini meliputi membuat, mengidentifikasi bahan ajar dan membeli kebutuhan, sehingga mencapai tujuan pembelajaran yang telah ditentukan.

\section{Implementation (melaksanakan)}

Tahap implementasi dilaksanakan pada sekolah yang ditunjuk sebagai tempat penelitian. Peneliti mendapatkan data terkait dengan nilai kepraktisan penggunaan media Board Game. Melalui penyebaran angket respon kepada peserta didik mengenai butirbutir pernyataan tentang penggunaan media Board Game dalam pembelajaran. Analisis berdasarkan hasil angket respon peserta didik guna mengetahui nilai kepraktisan media Board Game yang dikembangkan.

\section{Evaluation (mengevaluasi)}

Peneliti dapat melakukan evaluasi, sepanjang pelaksanaan kelima tahapan dalam model ADDIE. Hal ini bertujuan agar media yang telah dikembangkan sesuai dengan yang dibutuhkan dan dapat digunakan oleh pihak sekolah secara lebih luas lagi.

\section{METODE}

Penelitian ini termasuk jenis penelitian pengembangan atau Research and Development (R\&D). Pengembangan (R\&D) merupakan suatu proses mengembangkan produk baru atau menyempurnakan produk yang sudah ada, melalui beberapa tahapan meneliti, merancang, memproduksi dan menguji validitas produk yang telah dihasilkan secara ilmiah (Sugiyono, 2011).

Produk yang dihasilkan dalam penelitian ini berupa media pembelajaran Board Game materi Bilangan Berpangkat dan Bentuk Akar kelas IX SMP, dengan nama Board
Game Zathura Matematics. Metode yang digunakan dalam mengembangkan media Board Game Zathura Matematics menggunakan metode ADDIE yang terdiri dari 5 tahap yaitu analysis (analisis), design (desain), development (pengembangan), implementation (implementasi), dan evaluation (evaluasi).

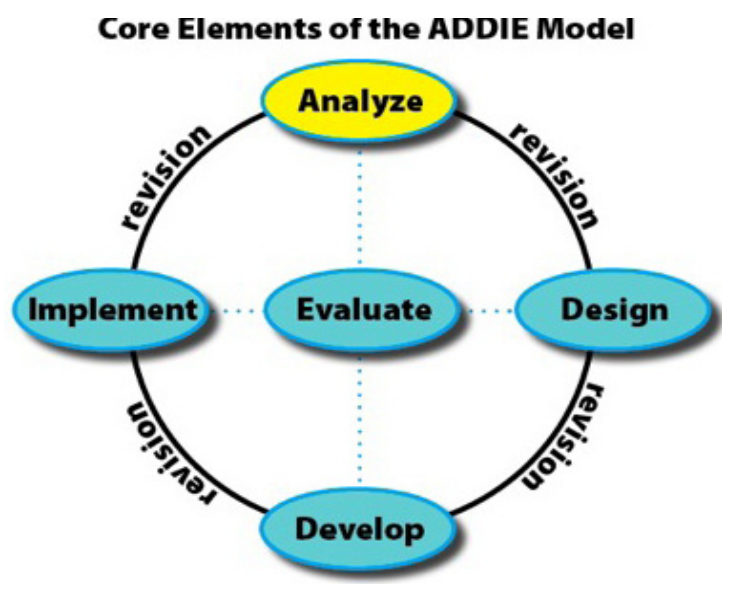

Gambar 1. Desain Metode Penelitian

Penelitian ini dilaksanakan di SMP Negeri 2 Tuntang yang terdiri dari 30 siswa kelas IXD. Media diujicobakan pada kelas IX D yang sudah memperoleh materi Bilangan Berpangkat dan Bentuk Akar. Teknik pengumpulan data yang digunakan dalam mengembangkan media Board Game adalah menggunakan angket respon peserta didik. Terdapat tiga instrumen yang digunakan peneliti yaitu lembar penilaian validasi, lembar penilaian kepraktisan dan angket respon siswa. Lembar validasi dipergunakan untuk mengukur kesesuaian materi dan kelayakan media sebelum diujicobakan. Lembar penilaian kepraktisan digunakan untuk mengukur kepraktisan media yang dihasilkan, Sedangkan angket respon peserta didik dibutuhkan untuk mengetahui respon sebelum menggunakan dan sesudah menggunakan media.

Hasil dari penilaian validasi, seperti validasi media, materi, dan kepraktisan merupakan data kualitatif dan kuantitatif. Data kualitatif dalam bentuk kritik dan saran yang dijadikan sebagai pedoman peneliti dalam memperbaiki media board game yang dikembangkan agar menjadi lebih baik. Sedangkan, data kuantitatif berupa hasil penilaian dari 
ahli materi dan ahli media yang akan dianalisis secara deskriptif. Terdapat 4 interval dalam skor penilaian antara lain (1) Sangat Baik, (2) Baik, (3) Cukup baik, dan (4) Tidak Baik. Dalam menghitung $\mathrm{P}(\mathrm{s})$ presentasi kelayakan menggunakan rumus (i) dirujuk pada interval skor penilaian Board Game berdasarkan ketentuan. Ketentuan pengkategorian sebagai berikut pada Tabel 1.

$$
P(s)=x 100 \% \ldots(i)
$$

Keterangan: $P(s)=$ Persentase sub variable; $S=$ Jumlah skor tiap sub variable; $N=$ Jumlah skor maksimum.

Tabel 1. Kategori Penilaian Validasi Board Game

\begin{tabular}{cc}
\hline interval & kriteria \\
\hline $83 \% \leq$ skor $\leq 100 \%$ & Sangat Baik \\
$62 \% \leq$ skor $\leq 83 \%$ & Baik \\
$41 \% \leq$ skor $\leq 62 \%$ & Cukup Baik \\
$20 \% \leq$ skor $\leq 41 \%$ & Tidak Baik \\
\hline
\end{tabular}

Penelitian ini menghasilkan media pembelajaran berupa Board Game Zathura Mathematics. Media Board Game ini dinyatakan valid dan praktis jika hasil penilaian para ahli materi dan media minimal 62\% (minimal kategori baik).

\section{HASIL DAN PEMBAHASAN}

Penelitian ini mengembangkan media pembelajaran Board Game Zathura Matematics materi bilangan berpangkat dan bentuk akar dengan model ADDIE. Sesuai dengan model ADDIE, proses pembuatan media pembelajaran Board Game Zathura Matematics sebagai berikut uraiannya:

\section{Analysis (Analisis)}

Proses awal dalam pengembangan Board Game ini adalah tahapan analisis, yaitu analisis karakter peserta didik dan analisis kebutuhan. Peserta didik tingkat menengah pada rentang usia 13-15 tahun memiliki karakteristik suka bermain atau sangat aktif. Pemberian media yang di dalamnya terdapat unsur permainan dan dapat menarik peserta didik untuk menggali informasi dan penge- tahuan perlu diperhatikan oleh guru. Melalui permainan yang dapat dilakukan secara berkelompok, maka pesera didik diharapkan dapat aktif di kelas dan dapat berinteraksi dengan baik di lingkungannya.

Pada tahap analisis kebutuhan dapat disimpulkan bahwa peserta didik yang hanya berlatih dengan lembar pertanyaan atau LKS menyebabkan kejenuhan dan mengantuk pada saat proses belajar. Terdapat beberapa alternatif yang dapat digunakan untuk merangsang peserta didik agar tidak jenuh dalam berlatih soal, misalnya adalah mengemas soal-soal latihan menjadi kegiatan yang menarik melalui permainan. Memodifikasi Board Game dengan adanya tantangan-tantangan dalam belajar akan menarik perhatian peserta didik.

Pengembangan Board Game dalam penelitian ini akan dipergunakan sebagai sarana latihan soal bilangan berpangkat dan bentuk akar, sehingga diperlukan analisis kebutuhan. Indikator bilangan berpangkat dan bentuk akar meliputi (1) Mengidentifikasi bilangan berpangkat bulat positif. (2) Menemukan sifat-sifat bilangan berpangkat dan bentuk akar. (3) Menentukan hasil operasi aljabar yang melibatkan bilangan berpangkat dan bentuk akar.

\section{Design (Desain)}

Setelah diperoleh rancangan Board Game Zathura Matematics dilanjutkan dengan mengembangkan media yang meliputi tahap pembuatan atau penyusunan. Tahap ini meliputi merancang aturan dan cara bermain serta alat-alat dalam Board Game, seperti kartukartu, pion dan lintasannya.

Media Board Game Zathura Matematics didesain untuk dimainkan maksimal oleh 4 orang pemain. Pembuatan mengenai aturan dan tata cara bermain telah disesuaikan agar dipahami, sehingga pemain tidak kebingungan ketika berbain media ini. Setiap pemain harus mempunyai tanggung jawab atas dirinya sendiri ketika bermain dalam sebuah kelompok. Aturan dan cara bermain Board Game Zathura Matematics disajikan pada Gambar 2.

Sesudah aturan dan cara main dibuat, selanjutnya disusun detail desain alat-alat yang akan digunakan dalam media Board 


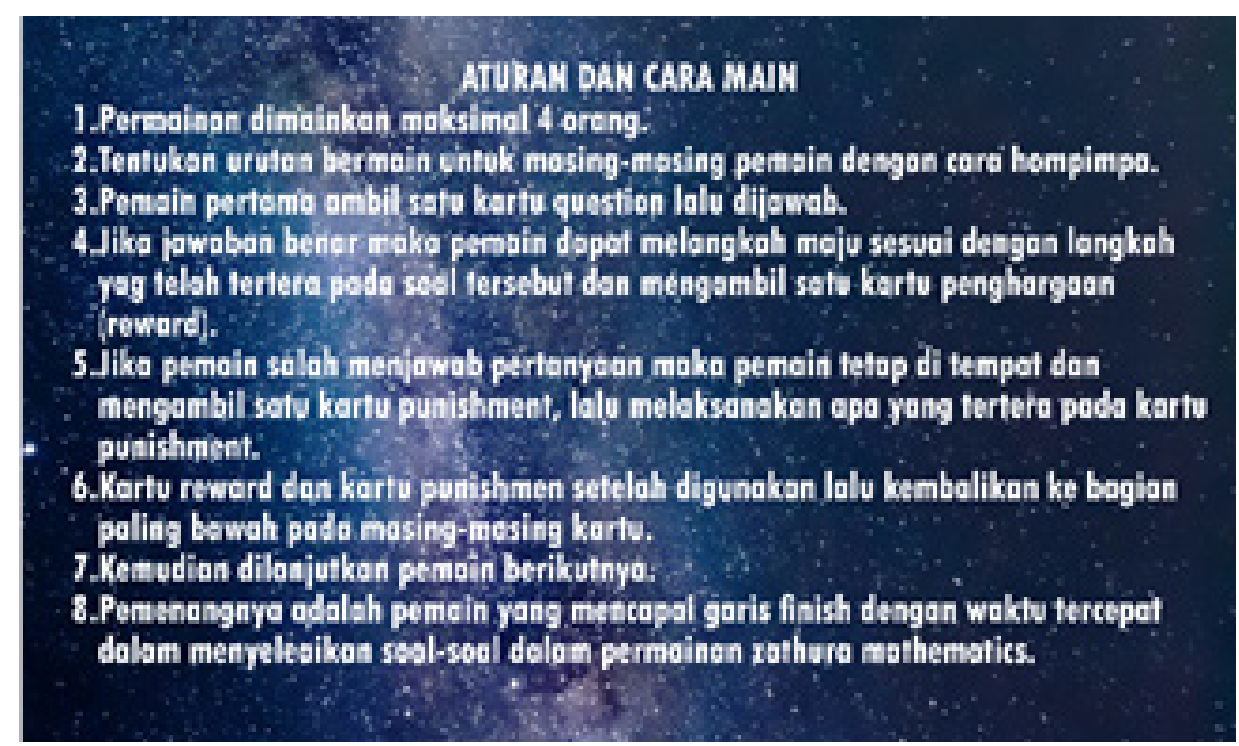

Gambar 2. Aturan dan Cara Bermain Board Game

Game Zathura Matematics diantaranya adalah lintasan Zathura, kartu question, kartu reward, kartu punishment serta pion. Lintasan Zathura dibuat sesuai dengan permainan zathura pada umunya yaitu dengan tema luar angkasa, hanya dimodifikasi dengan lintasan menggunakan sebuah bidak, terdapat 40 bidak tangga dari start menuju finish. Papan Zathura juga dimodifikasi dengan menggunakan akrilik, ukuran lebar $\mathrm{A}_{3}$ dengan ketebalan 3mm. pembuatan papan ini dengan 2 lapis akrilik yang dibaut berukuran $\mathrm{A}_{3}$ lalu dibagi menjadi 2 bagian berukuran $A_{4}$, tujuannya adalah agar mempermudah pembawaan dan penyimpanannya. Lintasan Zathura dapat dilihat pada Gambar 3 .

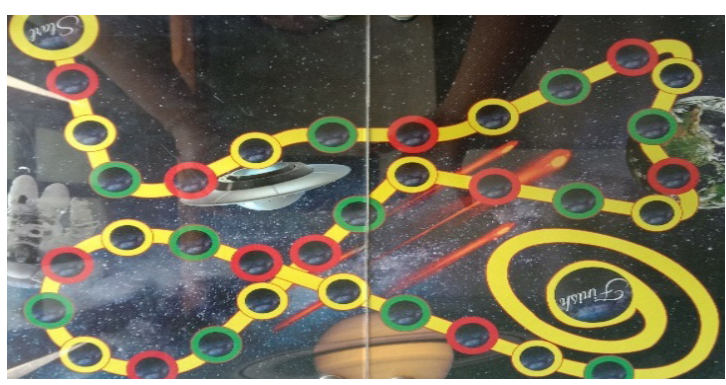

Gambar 3. Lintasan Zathura

Kartu question terdapat 50 soal. Terdiri dari 3 indikator (1) Mengidentifikasi bilangan berpangkat bulat positif. (2) Menemukan sifat-sifat bilangan berpangkat dan bentuk akar. (3) Menentukan hasil operasi aljabar yang melibatkan bilangan berpangkat dan bentuk akar. Bagian kartu question terdiri dari soal dan poin, dibagian atas terdapat pertanyaan lalu dibawahnya terdapat keterangan mengenai poin (langkah) yang didapat jika menjawab soal tersebut dengan benar. Poin yang didapat antara 1 sampai 3 langkah, sesuai dengan tingkat kesulitan soal yang didapat. Kartu reward terdiri dari 15 kartu dengan 4 kategori yaitu 1) bantuan jawaban, 2) ambil kartu question lagi, 3) lembar pertanyaan dan 5) ambil pertanyaan. Selanjutnya kartu punishment, terdiri dari 15 kartu dengan 5 kategori seperti kembali ke start, tidak ikut main 1 putaran dan mundur 1 sampai 3 langkah.

Desain kartu Zathura dibuat sama semua, pembedanya bagian depan terdapat keterangan mengenai kartu termasuk jenis question, rewart atau punishment. Desain kartu Zathura dapat dilihat pada Gambar 4.

Terdapat 4 pion yang digunakan dalam media pembelajaran Board Game Zathura mathematics. Pion yang dibuat dengan tema luar angkasa yaitu bentuk roket. Pemilihan warna yang berbeda-beda agar mudah membedakan antara pion satu dengan yang lainnya. Desain pion dapat dilihat pada Gambar 5. 

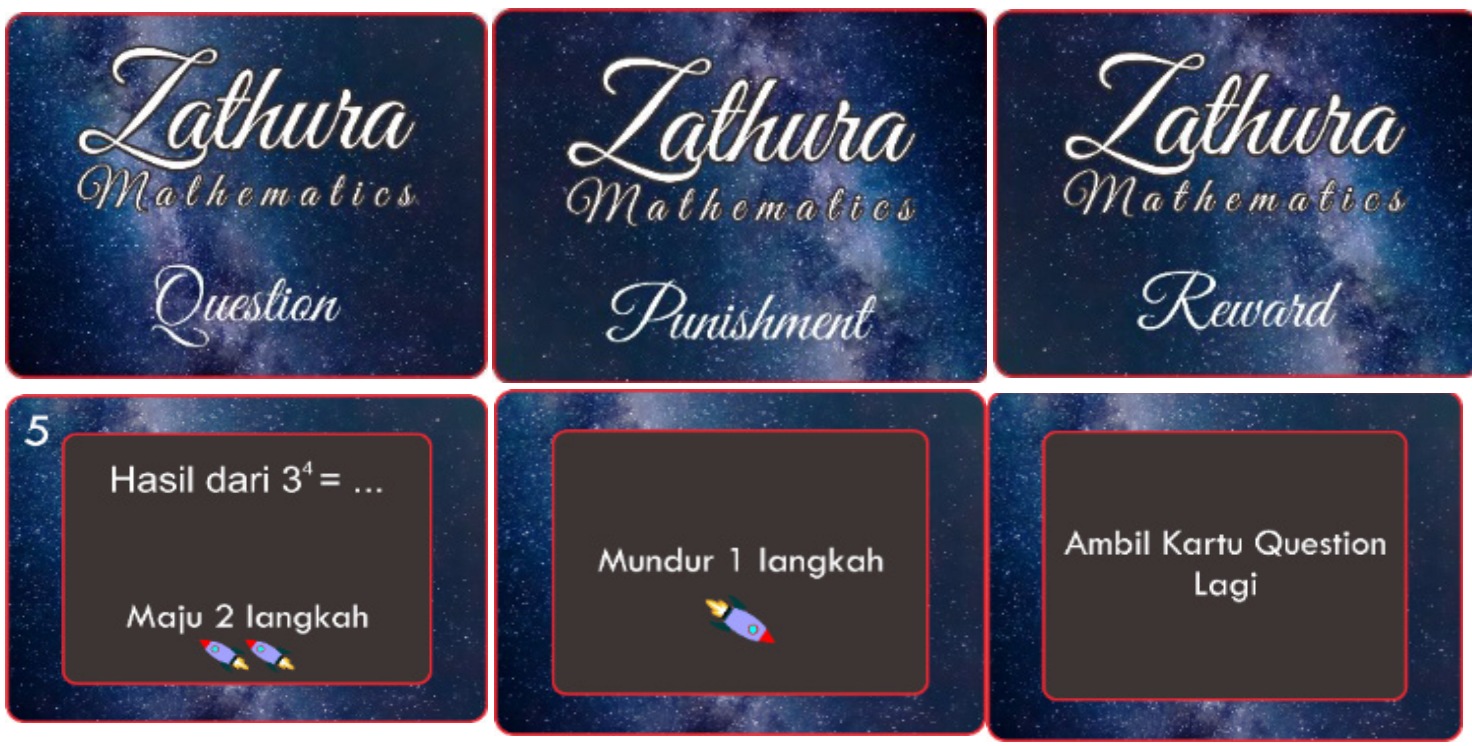

Gambar 4. kartu Zathura

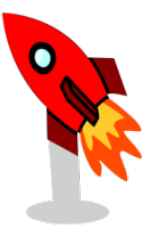

Gambar 5. Pion

Selain keempat alat-alat tersebut, terdapat beberapa alat tambahan seperti lem- bar petunjuk, tempat untuk meletakkan kartu question, reward, punishmen, pion serta kardus untuk media secara keseluruhan (kemasan). Lembar petunjuk berisikan prolog, alat-alat permainan, aturan dan cara bermain, penggunaan kartu reward dan punishment, serta kunci jawaban. Kunci jawaban dibuat guna memudahkan pengguna dalam pengecekan jawaban para pemain. Desain lembar petunjuk disajikan pada Gambar 6.
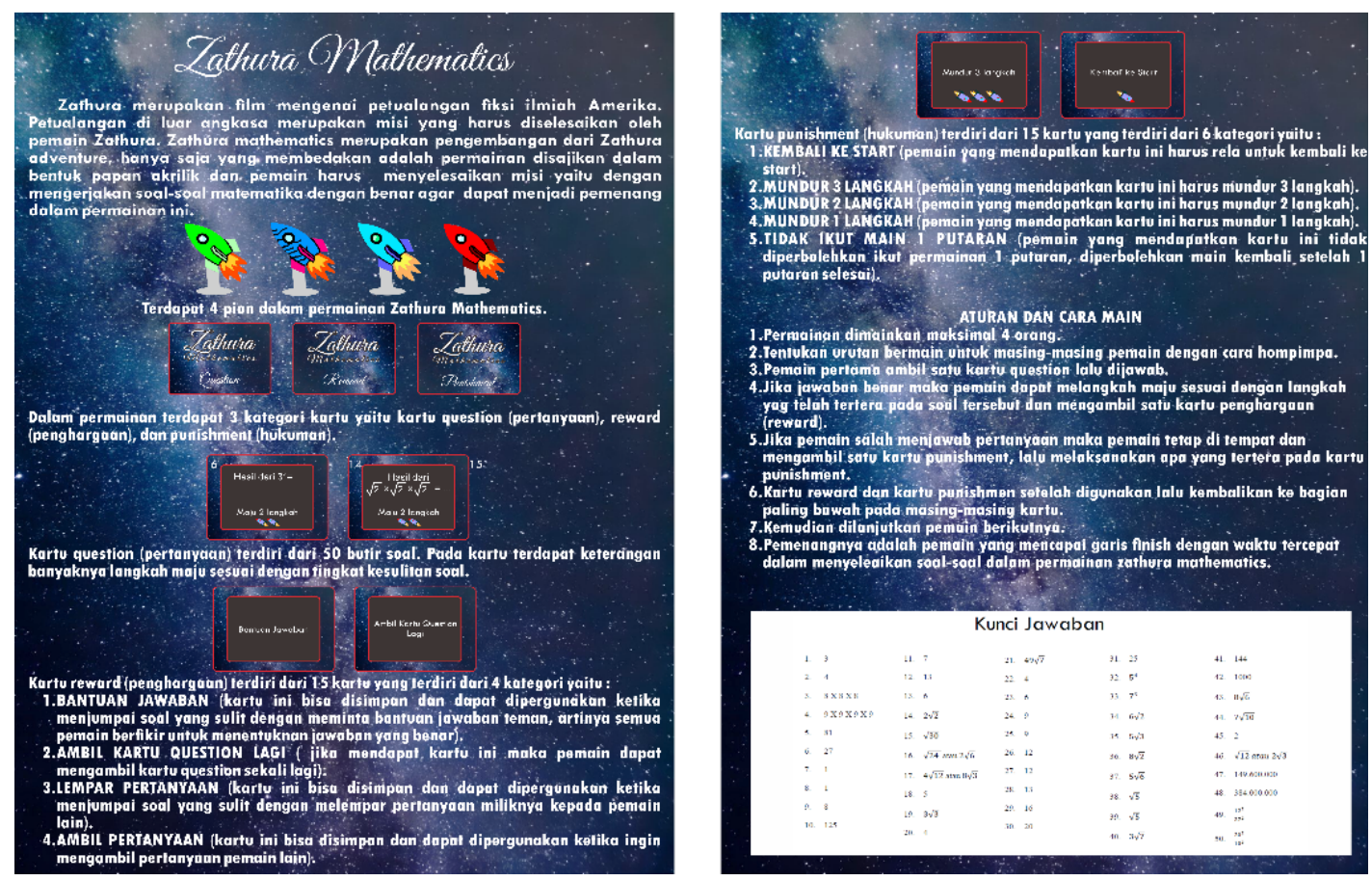

Gambar 6. Lembar Petunjuk 

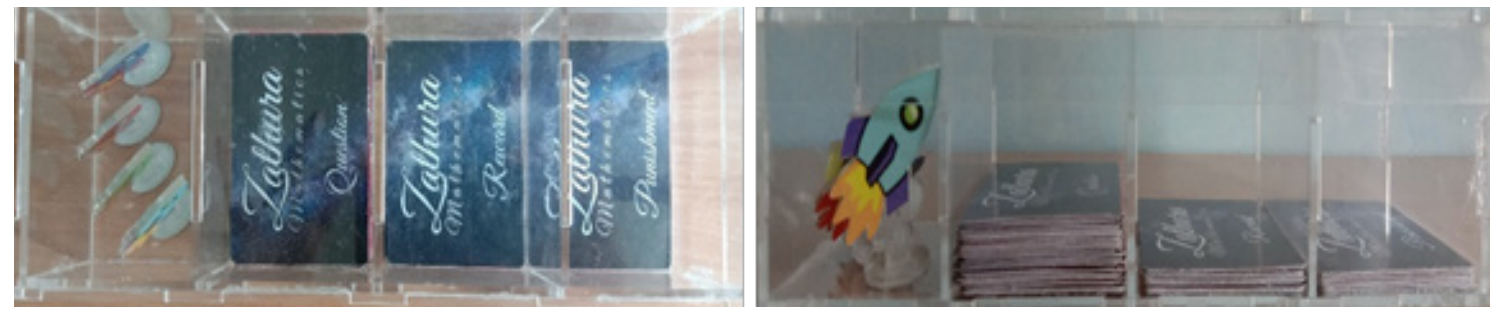

Gambar 7. Tempat Meletakkan Kartu Dan Pion

Box tempat untuk meletakkan jenisjenis kartu dan pionberisikan 4 kotak yang berukuran $26 \mathrm{~cm} \times 8 \mathrm{~cm}$, setiap kotak masingmasing berukuran $6 \mathrm{~cm} \times 8 \mathrm{~cm}$ dengan pembatas untuk tiap macamnya. Kotak tersebut dipisahkan berdasarkan jenis kartu yaitu question, reward, punishmen dan pion. Hal tersebut bertujuan untuk memudahkan siswa ketika pengambilan kartu. Desain dapat dilihat pada Gambar 7.

Pengemasan media Board Game memperhatikan beberapa aspek diantaranya yaitu kepraktisan dan keawetan. Kartu-kartu question, reward, punishmen dan pion dikemas dalam box kecil dari akrilik. Media dikemas menggunakan kardus tebal dengan dilapisi stiker vinyl agar awet dan tidak mudah rusak ketika disimpan. Kardus kemasan media ukurannya dibuat seminimal mungkin sesuai ukuran alat-alat yang digunakan dalam Board Game. Hal tersebut bertujuan agar mudah untuk dibawa dan disimpan karena ukurannya yang tidak terlalu besar. Pengemasan media Board Game disajikan dalam Gambar 8.

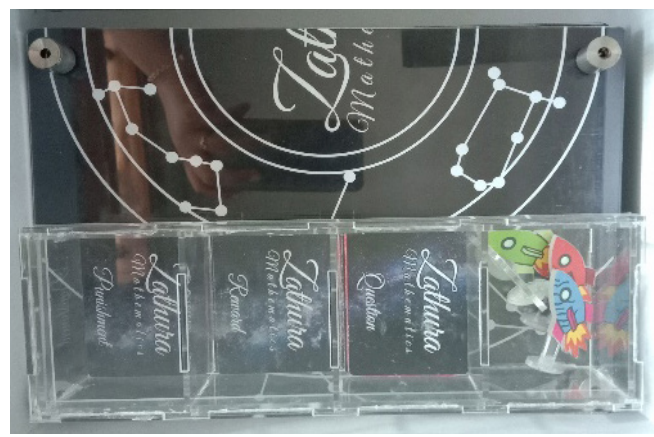

Gambar 8. Pengemasan Media

\section{Development (Pengembangan)}

Pada tahap ini sebelum diujicobakan kepada subjek perlu dilakukan validasi, yaitu oleh validator ahli seperti dosen dan guru.
Validasi bertujuan untuk mengetahui media Board Game layak dalam kegiatan pembelajaran. Validator mengisi instrument yang telah disusun peneliti pada tahap desain. Validator materi terdiri dari guru SMP N 2 Tuntang yaitu Ibu Andri Irawati, S.Pd. dan dosen Pendidikan matematika UKSW yaitu Bpk Tri Nova Hasti Yunianta, M.Pd. Hasil penilaian validasi oleh ahli materi disajikan dalam Tabel 2.

Tabel 2. Penilaian Validasi Ahli Materi

\begin{tabular}{ccc}
\hline Aspek penilaian & Presentase & Kategori \\
\hline Aspek Materi & $88 \%$ & Sangat Baik \\
Aspek Soal & $88 \%$ & Sangat Baik \\
Aspek Konstruksi & $88 \%$ & Sangat Baik \\
Rata-Rata & $88 \%$ & Sangat Baik \\
\hline
\end{tabular}

Hasil validasi ahli materi pada Tabel 2 menunjukkan bahwa pada aspek materi, soal, dan konstruksi masuk ke dalam kategori Sangat Baik. Kedua validator materi menganggap bahwa pertanyaan di papan permainan telah bervariasi dan termasuk indikator dalam materi Bilangan Berpangkat dan Bentuk Akar, Serta rata-rata presentase sebesar $88 \%$ yang termasuk dalam kategori valid. Sehingga Board Game dinyatakan valid dari aspek materi.

Validator ahli media pada media Board Game yaitu Bpk Tri Nova Hasti Yunianta, M.Pd. Hasil penilaian validasi oleh ahli media disajikan dalam Tabel 3.

Table 3. Penilaian Validasi Ahli Media

\begin{tabular}{ccc}
\hline Aspek penilaian & Presentase & kategori \\
\hline Tampilan Umum & $90 \%$ & Sangat Baik \\
Aturan Bermain & $75 \%$ & Baik \\
Pembuatan & $75 \%$ & Baik \\
Penggunaan dan & $100 \%$ & Sangat Baik \\
Pemeliharaan & & \\
Pengemasan & $88 \%$ & Sangat Baik \\
Kemanfaatan & $93 \%$ & Sangat Baik \\
\hline Rata-Rata & $87 \%$ & Sangat Baik \\
\hline
\end{tabular}


Hasil validasi ahli media pada Tabel 3 menunjukkan bahwa dari segi Tampilan Umum seperti nama media, design, ukuran Board Game dan perlengkapannya telah tepat. Aturan Bermain mudah dipahami, validator menilai telah sesuai. Pembuatan, Penggunaan dan Pemeliharaan media yang tahan lama, serta Pengemasannya sangat praktis, Kemanfaatan media sebagai sarana belajar juga bermain, menumbuhkan unsur kesenangan dalam belajar dan membuat siswa aktif, validator menilai bahwa aspek tersebut sesuai. Rata-rata presentase sebesar $87 \%$ yang termasuk dalam kategori valid. Sehingga Board Game dinyatakan valid dari aspek ahli media.

Berdasarkan Tabel 2. dan Tabel 3. Dapat disimpulkan bahwa media Board Game valid digunakan sebagai sarana latihan soal pada materi Bilangan Berpangkat dan Bentuk Akar. Para validator ahli media berpendapat bahwa media sesuai untuk menarik minat siswa dalam belajar, dengan tema yang menarik. Selain itu, kombinasi warna, jenis font dan ukuran yang cocok, dan memiliki komponen yang lengkap. Hasil penelitian ini hampir sama dengan penelitian yang dilakukan oleh (Harsono dan Prihatnani, 2018), (Irianto, Dkk, 2016), (Lufri, Fitri. R., Oktaviana. D, 2017), (Suprapti. E., Ainy. C., Wulandari. S, 2017), (Widianingtyas dan Budiharti, 2017), (Wulandari dan Budiharti, 2016) dan (Muftiatul. C dan A. A. Sujadi, 2014) menunjukkan bahwa media permainan valid dan tepat sebagai sarana belajar.

\section{Implementation (melaksanakan)}

Media Board Game Zathura Mathematics yang sudah dinyatakan valid selanjutnya diujicobakan, uji coba dilaksanakan pada siswa kelas IX D SMP Negeri 2 Tuntang. Sebelum penggunaan media, pada pertemuan sebelumnya peneliti melakukan observasi dan penyebaran angket tentang pembelajaran tanpa media.

Ketika media diujicobakan, validator menilai kepraktisan media. Adapun rekapitulasi hasil lembar kepraktisan oleh Ibu Andri Irawati, S.Pd. Hasil penilaian uji kepraktisan oleh ahli media disajikan dalam Tabel 4.
Tabel 4. Uji kepraktisan

\begin{tabular}{ccc}
\hline Aspek penilaian & Presentase & kategori \\
\hline Persiapan Penggunaan & $100 \%$ & Sangat Baik \\
Penggunaan & $100 \%$ & Sangat Baik \\
Rata-Rata & $100 \%$ & Sangat Baik \\
\hline
\end{tabular}

Hasil uji kepraktisan pada tebel 4 menunjukkan bahwa media Board Game Zathura Mathematics praktis sebagai latihan dalam belajar Bilangan Berpangkat dan Bentuk Akar. Hal ini hampir sama dengan penelitian Vitantri, Pradipta, dan Umah (2016: 42) menyatakan bahwa media Board Game monolita praktis sebagai media dalam pembelajaran matematika. Validator yang memberikan penilaian ini berpendapat bahwa melalui media ini dapat menumbuhkan interaksi antara siswa dan membuat siswa aktif.

\section{Evaluation (mengevaluasi)}

Media Board Game Zathura Mathematics diujicobakan kepada peserta didik yang telah mempelajari Bilangan Berpangkat dan Bentuk Akar. Sebelum diujicobakan penelii melakukan observasi dan penyebaran angket guna menggetahui motivasi dalam belajar matematika sebelum dan sesudah penggunaan media.

Hasil dari observasi yang dilakuan peneliti pada hari sabtu, 10 Agustus 2019 adalah beberapa peserta didik sudah aktif bertanya dan jika belum bisa memecahkan persoalan mereka berusaha dengan bertanya kepada teman ataupun guru untuk memecahkan persolannya. Tetapi peserta didik yang dominan duduk dibagian belakang tidak begitu memperhatikan ada yang melamun dan juga ada yang bercanda dengan teman sebangku. Setelah jam pelajaran hampir selesai peserta didik mengisi angket motivasi. Adapun ratarata hasil angket motivasi oleh peserta didik disajikan dalam Tabel 5.

Tabel 5. Perbandingan motivasi peserta didik

\begin{tabular}{cc}
\hline Penggunaan Media & Presentase \\
\hline Sebelum & $68 \%$ \\
Sesudah & $81 \%$ \\
\hline
\end{tabular}

Hasil uji perbandingan motivasi peserta didik sebelum dan sesudah menggunakan media Board Game Zathura Mathematics pada 
tabel 5 menunjukkan bahwa sebelum mengunakan media rata-rata nilai angket motivasi peserta didik dalam belajar sebesar $67 \%$ setelah menggunakan media pembelajaran motivasi peserta didik meningkat menjadi $81 \%$. Dari tabel di atas juga dapat dilihat dengan menggunakan media pembelajaran signifikan meningkaatkan motivasi pesserta didik sebesar $14 \%$.

Pengujian media Board Game Zathura Mathematics dilaksanakan pada hari rabu, 21 Agustus 2019. Pada tahap ini peneliti melakukan uji coba sekaligus observasi. Hasil observasi adalah peserta didik menjadi lebih aktif dalam meyelesaikan soal dengan berdikusi dengan kelompok, antara kelompok satu dengan yang lain juga menunjukkan daya saing yang positif untuk menjadi pemenang dalam permainan ini. Tidak hanya pengujian media, tetapi peserta didik juga diminta untuk mengisi angket motivasi setelah belajar menggunkan media dan juga mengisi lembar pendapat siswa. Hasil rekapitulasi lembar pendapat siswa dapat disajikan dalam Tabel 6.

Tabel 6. Hasil Rekapitulasi Lembar Pendapat Siswa

\begin{tabular}{|c|c|c|c|}
\hline \multirow[b]{2}{*}{ Indikator } & \multicolumn{2}{|c|}{ Keterangan } & \multirow{2}{*}{$\begin{array}{r}\text { Kesim } \\
\text { pulan }\end{array}$} \\
\hline & Setuju & $\begin{array}{l}\text { Tidak } \\
\text { Setuju }\end{array}$ & \\
\hline $\begin{array}{l}\text { Media mudah digu- } \\
\text { nakan }\end{array}$ & $100 \%$ & - & Setuju \\
\hline Media asyik digunakan & $100 \%$ & - & Setuju \\
\hline $\begin{array}{l}\text { Menumbuhkan keak- } \\
\text { tifan }\end{array}$ & $100 \%$ & - & Setuju \\
\hline Bermain sambil belajar & $100 \%$ & - & Setuju \\
\hline Persiapan bermain & $100 \%$ & - & Setuju \\
\hline Aturan bermain & $100 \%$ & - & Setuju \\
\hline Peluang keberhasilan & $88 \%$ & $12 \%$ & Setuju \\
\hline $\begin{array}{l}\text { Tertarik memainkan } \\
\text { kembali }\end{array}$ & $75 \%$ & $25 \%$ & Setuju \\
\hline
\end{tabular}

Berdasarkan hasil rekapitulasi Tabel 6 . Menunjukkan bahwa media mudah dan asyik digunakan dalam belajar. Media dapat menumbuhkan keaktifan peserta didik serta dapat belajar sambil bermain. Aturan permainan dan indikator media mudah digunakan, keenam indikator tesebut dalam kategori disetujui. Rekapitulasi pendapat siswa terhadap media disimpulkan setuju. Hasil penelitian ini menyerupai hasil penelitian yang dilakukan oleh (Rizal dan Hernawati, 2017), (Akhlis. I.,
Widiyatmoko. A., Wahyuni. T, 2015), (Suzana. A, 2017), (Masrukan., Susilo. BE., Setyowati, 2016) dan (Listiani dan Prihatnani, 2018). Hasil dari penelitian menyimpulkan bahwa media yang telah dikembangkan memiliki dampak positif pada minat dan hasil belajar siswa. Media pembelajaran yang dikembangkan valid dan praktis sebagai media pembelajaran.

\section{SIMPULAN}

Berdasarkan hasil penelitian beserta pembahasan yang telah diuraikan diatas, dapat disimpulkan bahwa media Board Game Zathura Mathematics dapat meningkatkan motivasi peserta didik dalam belajar. Tidak hanya itu media Board Game valid dari segi materi dan media pembelajaran dengan persentase $88 \%$ dan $87 \%$ dari kedua kategori tersebut masuk dalam kategori sangat baik dalam kategori materi maupun media pembelajaran. Nilai praktis pada media ini sebesar 100\% termasuk dalam kategori Sangat Baik. Berdasarkan hasil keseluruhan tes dinyatakan bahwa media Board Game Zathura Mathematics valid, praktis dan efektif sebagai media pembelajaran materi Bilangan Berpangkat dan Bentuk Akar pada peserta didik kelas IX.

\section{DAFTAR PUSTAKA}

Ahmad, H. (2017). Efektifitas Penggunaan Alat Peraga Kodama dalam Mengerjakan Soal Matematka Materi Persamaan Garis Lurus. Jurnal Pendidikan PEPATUDZU, 13(2), 118-132.

Akhlis. I., Widiyatmoko. A., Wahyuni. T., (2015). Efektivitas Penggunaan Media Audiovisual Pada Pembelajaran Energi Dalam Sistem Kehidupan Pada Siswa SMP. Unnes Science Education Journal. 4, 998-1004.

Andini, M., (2018). The Development of Board game "The Adventure Of Algebra" in The Senior High School Mathematics Learning. Al-Jabar J. Mat. 9, 95-109.

Anggreiny, A.A., (2018). Pengembangan Media Pembelajaran Fisika Berbasis Permainan Zathura Untuk Meningkatkan Minat Dan Hasil Belajar Fisika Peserta Didik Kelas XI SMA N 1 KRETEK. J. Pend. Fis. 530-540.

Erlitasari, N.D., Dewi, U., (2016). Pengembangan Media Board Game Garis Bilangan Materi Bilangan Bulat Mata Pembelajaran Matematika Kelas IV SDN Ngampelsari Candi Sidoarjo. J. Mhs. UNESA 1-12.

Ernata, Y., (2017). Analisis Motivasi Belajar Peserta Didik Melalui Pemberian Reward Dan Punishment di SDN Ngaringan $05 \mathrm{Kec}$. Gandusari Kab.Blitar. J. Pemikiran dan Pengembangan SD. 5, 781-790. 
Gianto, E.K.A., (2018). Pengembangan MOSIRI (Geometry Transformation Module) untuk Sekolah Tinggi siswa. Al-Jabar J. Mat. 9, 121-134.

Hendriana. (2017). Hard Skills Dan Soft Skills Matematik Siswa. Bandung: PT Refika Aditama.

Irianto, Dkk., (2016). Pengembangan Media Permainan Congklak Matematika Untuk Mengefektifkan Penyampaian Materi KPK DAN FPB Kelas IV Di Sekolah Dasar. J. Dinamika Pendidikan Dasar. 8, 34-39.

Latif, Y., Darmawijoyo., Ratu. I.I.P., (2013) Pengembangan Bahan Ajar Berbantuan Camtasia pada Pokok Bahasan Lingkaran melalui Edmodo untuk siswa MTs. Kreano J. Mat. Kreat. 4,

Listiani, D., Prihatnani, E., (2018). Pengembangan Media Pembelajaran Dart Board Math Bagi Siswa Kelas VII SMP. Math Didact. 4, 21-33.

Lufri, Fitri. R., Oktaviana. D., (2017) Pengembangan Media Pembelajaran Berbentuk Permainan Monopoli Tumbuhan (Montum) Tentang Struktur Dan Fungsi Tumbuhan Untuk Peserta Didik Kelas VIII SMP. J. Biosains. 1, 174-182.

Lutfianingsih, N., (2018). Pengembangan Media Pembelajaran Permainan QUESTIONS WHEEL CHAIN (OWC) Pada Materi Analisis Swot Di Kelas X BDPM Smk Negeri Pasirian. J. Pendidikan Tata Niaga. 6, 226-233.

Masrukan., Susilo. BE., Setyowati., (2016). Penggunaan Alat Peraga untuk Meningkatkan Hasil Belajar dan Keaktifan Siswa pada Materi Peluang. J. Mat. Kreat.-Inov. 7, 24-30.

Muftiatul. C dan A. A. Sujadi., (2014). Pembelajaran Matematika Dengan Metode Joyful Learning Dengan Media Papan Permainan Pada Materi Bilangan Bulat Kelas Vii Smp Muhammadiyah Sidareja. J. Pendidikan Maematika. 3, 265-272.

Pradipta, D. A., Vitantri, A. C. \& Umah, U., (2016). Pengembangan Game Edukatif Monolita sebagai Media Pembelajaran Matematika Siswa SMP. Ed-Humanistics: Jurnal Ilmu Pendidikan. 1(1), 36-43.

Putri, W.A., (2018). Pengembangan Media Pembelajaran Board Game "The Labyrinth Of Trigonometry"
Pada Materi Trigonometri Kelas X SMA. J. Satya. Widya. 36, 88-100.

Rizal, A., Hernawati, K., (2017). Pengembangan Game Edukasi Matematika Dengan Pendekatan Guided Discovery Untuk Siswa SMP Kelas VII. Jurnal Pendidik. Mat. 6, 1-8.

Rosa, D., (2018). Pengembangan Media Monopoli Matematika Pada Materi Peluang Untuk Siswa SMP. JRPM. 3, 114-131.

Setyadi, D., Qohar, A., (2017). Pengembangan Media Pembelajaran Matematika Berbasis Web Pada Materi Barisan Dan Deret. Kreano J. Mat. Kreat.Inov. 8, 1-7.

Sugiyono, (2009). Metode Penelitian Pendidikan. Alfabeta, Bandung.

Sugiyono, (2011). Metode Penelitian Kuantitatif, Kualitatif dan R\&D. Jakarta : Alfhabeta

Suprapti, E., Ainy, C., Wulandari. S., (2017). Pengembangan Media Pembelajaran Matematika Berbasis Game Interaktif Menggunakan Aplikasi Adobe Flash Cs3 Pada Materi Pokok Trigonometri Kelas X SMKN 10 Surabaya. Jurnal of Mathematics Education, Science and Technologi. 2,165-177.

Suprihatin, S., (2015). Upaya Guru Dalam Meningkatkan Motivasi Belajar Siswa. J. Promosi. Ekonomi. 3, 73-82.

Suzana, A., (2017). Pengaruh Penerapan Permainan Kartu Domino Terhadap Prestasi Belajar Matematika Siswa Kelas X. J. MathGram. 2, 1-9.

Triastuti, D., Akbar, S., (2016). Penggunaan Media Papan Permainan Untuk Meningkatkan Motivasi Belajar Siswa Di Sekolah Dasar. J. Pascasar. Univ. malang. 3, 1-7.

Widianingtyas, F.I., Budiharti, (2017). Pengembangan Media Pembelajaran Papan Bajahitam (Bahasa Jawa dan Hitung Matematika) Ditinjau Dari Prestasi Belajar Siswa Kelas IV Di SDN Suryodiningrat 3 Yogyakarta. J. PGSD Indonesia. 3, 1-16.

Wulandari, D.G.R., Budiharti, (2016). Pengembangan Media Pembelajaran Kantong Nilai Plastik Transparan Untuk Menanamkan Konsep Operasi Hitung Bilangan Disekolah Dasar. Respository UPY. 